\title{
Gamete interactions in teleost fish: the egg envelope. Basic studies and perspectives as environmental biomonitor
}

\author{
Nibia Berois, María J. Arezo, Nicolás G. Papa \\ Sección Biología Celular, Instituto de Biología. Facultad de Ciencias. Universidad de la República. Montevideo, República Oriental del Uruguay.
}

\begin{abstract}
The current knowledge about teleost fish egg envelope is summarized. The paper analyzes the organization and deposition process of the protein composition and genes involved in the synthesis of teleost fish egg envelopes and their role in gamete interaction during fertilization. Pelagic and demersal species that our research group is working with are especially considered. The vertebrate ZP family of proteins, the evolution and relationship among the different genes and their expression are taken into account. We consider fish envelope as a possible biomonitor for ecological contaminants. The biotechnological applications for aquaculture and genomic and post-genomic approaches are auspicious.
\end{abstract}

Key words: fish egg envelope, ZP genes.

\section{INTRODUCTION}

Teleost fertilization exhibits special distinct characteristics from those of other vertebrates and even other fish groups. The oocyte is covered by the vitelline envelope (eggshell, zona pellucida, zona radiata or chorion) as in all vertebrate species, but sperm interaction only occurs at the micropyle level. This special teleostean oocyte structure, located at the animal pole, serves as the only entry site for the male gamete and is formed during the egg envelope deposition. It shows morphological differences among species with taxonomic value (Guraya, 1986). In general, it is a funnel-shaped channel whose inner diameter is similar to the sperm head of the species (Hart, 1990). As teleost sperm lacks acrosome, during fertilization there is no acrosome reaction (Guraya, 1986; Hart, 1990). The sperm fuses to the oocyte cell membrane underlying the micropyle and special structures there, such as microvilli or folds, have been reported in some fish (Brummett and Dumont, 1979; Dumont and Brummett, 1980; Hart and Donovan, 1983). In the surface of both gametes lies the key to species-specificity. Consequently, the ultrastructure of egg envelope, micropyle and sperm head are features that considered in phylogenetic analyses and pre-zygotic isolation among closely related species.

In contrast to mammals, where the zona pellucida is involved in sperm binding, in teleosts a single sperm reaches the egg membrane through the micropyle. After the egg is activated by the sperm, the micropyle closes, preventing polyspermy. The vitelline envelope possesses many other functions, such as protection of the growing oocyte and the developing embryo and uptake of nutrients and other molecules during oogenesis, guidance of the sperm to the micropyle (Dumont and Brummet, 1980), as well as possessing bactericidal and fungicidal properties (Kudo and Inoue, 1989; Kudo, 2000).

According to the behavior after ovulation, fish generate two kinds of eggs: a) pelagic highly hydrated eggs that float in seawater; b) demersal non-buoyant eggs, generally in freshwater, which attach to plants or substrate. The oocyte envelope structure is related to environmental conditions. Generally, fish that spawn pelagic eggs are non-adhesive and smooth, with poorly ornamented envelopes, whereas those that place their eggs over plants or on the bottom have sticky and ornamented eggs (Rizzo et al., 2002).

The oocyte envelope appears to be a sensitive biomarker to adverse pollutants. Changes in ZP synthesis and organization of egg envelopes have been reported in both kind of oocyte envelope (pelagic and demersal) as a consequence of aquatic contaminants (especially xenoestrogens) (Arukwe et al., 1997; Arukwe and Goksøyr, 2003).

\section{Framework and objective of the present paper}

Our research group is interested in different aspects of reproductive biology of teleost fish both in fishing resources and laboratory models. Among the former is the whitemouth croaker (Micropogonias furnieri) (Perciformes; Sciaenidae), a migratory euryhaline teleost fish living in the Atlantic Ocean from Northern Venezuela $\left(20^{\circ} \mathrm{N}\right)$ to the Gulf of St. Mathias $\left(41^{\circ} \mathrm{S}\right)$ (FAO, 1974; Chao, 1978). In the Rio de la Plata, this species is the most abundant sciaenid and constitutes an important resource for the Uruguayan and Argentinean fisheries (Ehrhardt et al., 1977; Arena, 1990). Histological and cellular studies show that the population inhabiting the Rio de la Plata is a multiple spawner that reproduces on the Uruguayan coast between October and February (Berois et al., 2004).

Considering laboratory models, the research group has focused on annual fish. Although zebrafish (Danio rerio) and medaka (Oryzias latipes) are the most often used teleost models in developmental biology, species of annual fish (Cyprinodontiformes; Aplocheiloidei) are excellent for comparative analyses. They have a short lifespan and are exposed to an extremely variable environment. They 
inhabit temporary ponds from Africa and South America that undergo drying during summer. This condition leads to the death of the entire young and adult populations. The survival of the species is entirely dependent on embryos that remain buried in the bottom mud and hatch in the next rainy season (Wourms, 1964, 1967). In contrast to other teleost fish, annual exhibit a unique developmental pattern (Myers, 1952). Epiboly is temporally and spatially detached from organogenesis and embryos undergo one or more reversible arrest (diapauses) at three different stages: diapause I at dispersed stage during epiboly; diapause II at middle somite stage and diapause III at pre-hatching (Wourms, 1972 a,b,c) (Arezo et al., 2005). These developmental adaptations are closely related to the life cycle.

As a tribute to the scientific contribution of Dr. Claudio Barros, the aim of the present paper is to review the information about fish egg envelopes referring to pelagic and demersal oocytes, mainly from the research accomplished with or since his collaboration. Dr. Barros enjoyed teaching and encouraged his students to face the challenges that appeared with each step of their work as a new opportunity to advance and grow. His words and witty remarks will always be with us.

\section{ORGANIZATION AND DEPOSITING PROCESS OF TELEOST EGG ENVELOPE}

The fish oocyte develops within the ovarian follicle, which is a structure organized in the early stages of oogenesis before uptake of the yolk. It is formed by the oocyte surrounded by the granulose or follicular cells, the theca cells and a basement lamina as the outer limit of the follicle (Wallace and Selman, 1981). Teleost oogenesis can be divided into five stages: pre-vitellogenic, lipid-yolk, protein-yolk, fully-grown and mature oocyte (Berois et al., 2004). The formation of the envelope, through depositing of successive layers, occurs during the lipid-yolk to fully-grown stages, at the same time as vitellogenesis. During this time the oocyte cell membrane projects microvilli toward the granulose cell of the follicle. Other microvilli from these cells are observed afterwards. The synthesis of the egg envelope starts from the base of the oocyte microvilli and reaches the maximal width and complexity at the fully-grown stage when it acquires a trilaminar structure (Wallace and Selman, 1981; Berois et al., 2007).

At the ultrastructural level (transmission electron microscopy, TEM) the oocyte envelope of the fully grown oocyte (Fig 1 A) shows an outermost fine granular layer, a middle and homogeneous high electron dense layer and the innermost and wider layer, known as zona radiata interna, with a helicoidal-fibrilar aspect (Fig. 1 C). There are numerous channels cross the entire width of the chorion in a regular pattern, each occupied by oocyte and follicle cell microvilli in close apposition (Fig. 1D,E) (Dumont and Brummett, 1980; Hart and Donovan, 1983; Guraya, 1986; Cotelli et al., 1988; Arezo et al., 2007; Berois et al., 2007; Modig et al., 2008). In mature and ovulated pelagic oocytes (Fig. $2 \mathrm{~A}$ ), the egg envelope became thinner and loses its trilaminar and radial striations, showing parallel bands of different electron density (Fig 2 B). Channels and microvilli are no longer identifiable (Berois et al., 2007; Modig et al., 2007). After fertilization, a perivitelline space is formed and the egg envelope hardens and becomes the fertilization envelope (Guraya, 1986; OppenBerntsen et al., 1990).
Comparing the oocyte envelope surface of two fish species, the whitemouth croaker, Micropogonias furnieri (pelagic spawner) and the Austrolebias charrua (demersal spawner), we can identify by scanning electron microscopy (SEM) that: a) the whitemouth croaker oocyte envelope is smooth, with a regular pattern of empty pores that represent the external openings of oocyte envelope channels. The surface pattern is consistent with the condition of neutrally buoyant pelagic eggs described for the species (Fig. 3 A) (Isaac-Nahum, 1988; Berois et al., 2007); b) the Austrolebias egg envelope shows a rough and sticky surface ornamented by hair-like cone-shaped filaments in accordance to its demersal condition (Fig. 3 B) (Arezo et al., 2007).

\section{PROTEIN COMPOSITION}

Knowledge about the biochemistry, development and functions of the vertebrate vitelline envelope has expanded as a consequence of the advance in molecular approaches. Alignments of teleost chorion proteins with vitelline envelope proteins from other vertebrate species or zona pellucida proteins (ZPs) indicate that these molecules have been highly conserved during evolution. They show high homology with vitelline envelope proteins of amphibians, birds and mammals, except for the sperm-recognition sequence, which has only been found in mammals. This general similarity suggests that they form a unique group of vertebrate proteins, which function as structural components of the vitelline envelope and are highly conserved (Hyllner et al., 2001; Listcher and Wassarman, 2007)

Most ZP proteins have an N-terminal signal peptide, a conserved $\mathrm{ZP}$ domain, a furin cleavage site and a hydrophobic C-terminal. This C-terminal is formed by a transmembrane domain (TMD) and a short cytoplasmic tail. The ZP domain contains about 260 amino acids with $10 \neg 12$ cystein residues. It is also a common feature in many extracellular matrix proteins (Bork and Sander, 1992).

In spite of the ambiguous nomenclature for egg envelope proteins (choriogenin proteins, $\mathrm{ChP}$, zona pellucida proteins, $\mathrm{ZP}$, zona radiata proteins, $\mathrm{ZRP}$, or vitelline envelope proteins, VEP) four groups of $\mathrm{ZPs}$, all containing the conserved $\mathrm{ZP}$ domain signature, have been identified in vertebrates: $Z P A$, $\mathrm{ZPB}, \mathrm{ZPC}$ and ZPX. While ZPB and ZPC were found in all vertebrates, $Z P X$ was identified in frogs, chicken and fish and ZPA has not been found so far in fish (Spargo and Hope, 2003).

Comparison of the envelope protein profile among teleost species shows that most share a similar pattern of protein and glycoprotein bands, regardless of their habitats (freshwater or seawater). Major oocyte envelope constituents have molecular masses ranging between 40 and $130 \mathrm{kDa}$ (Hamazaki et al., 1987a; Cotelli et al., 1988; Begovac and Wallace, 1989; Brivio et al., 1991; Oppen-Berntsen et al., 1990; Hyllner et al., 1991; Scapigliati et al., 1994; Bonsignorio et al., 1996; Berois et al., 2007). The Austrolebias egg envelope protein profile analyzed by SDS-PAGE shows seven bands in mature oocytes: four major bands with molecular weights of about 45, 97, 120 and $160 \mathrm{kDa}$. Bands of 97 and $120 \mathrm{kDa}$ are glycoproteins. More detailed analyzes are currently in progress. The whitemouth croaker protein profile reveals five bands for fully grown oocytes: two major bands with molecular weights of about 47 and $57 \mathrm{kDa}$, and three minor bands of about 67, 110 and $130 \mathrm{kDa}$. Bands of 47, 57 and $130 \mathrm{kDa}$ are glycoproteins. In mature ovulated oocytes these 

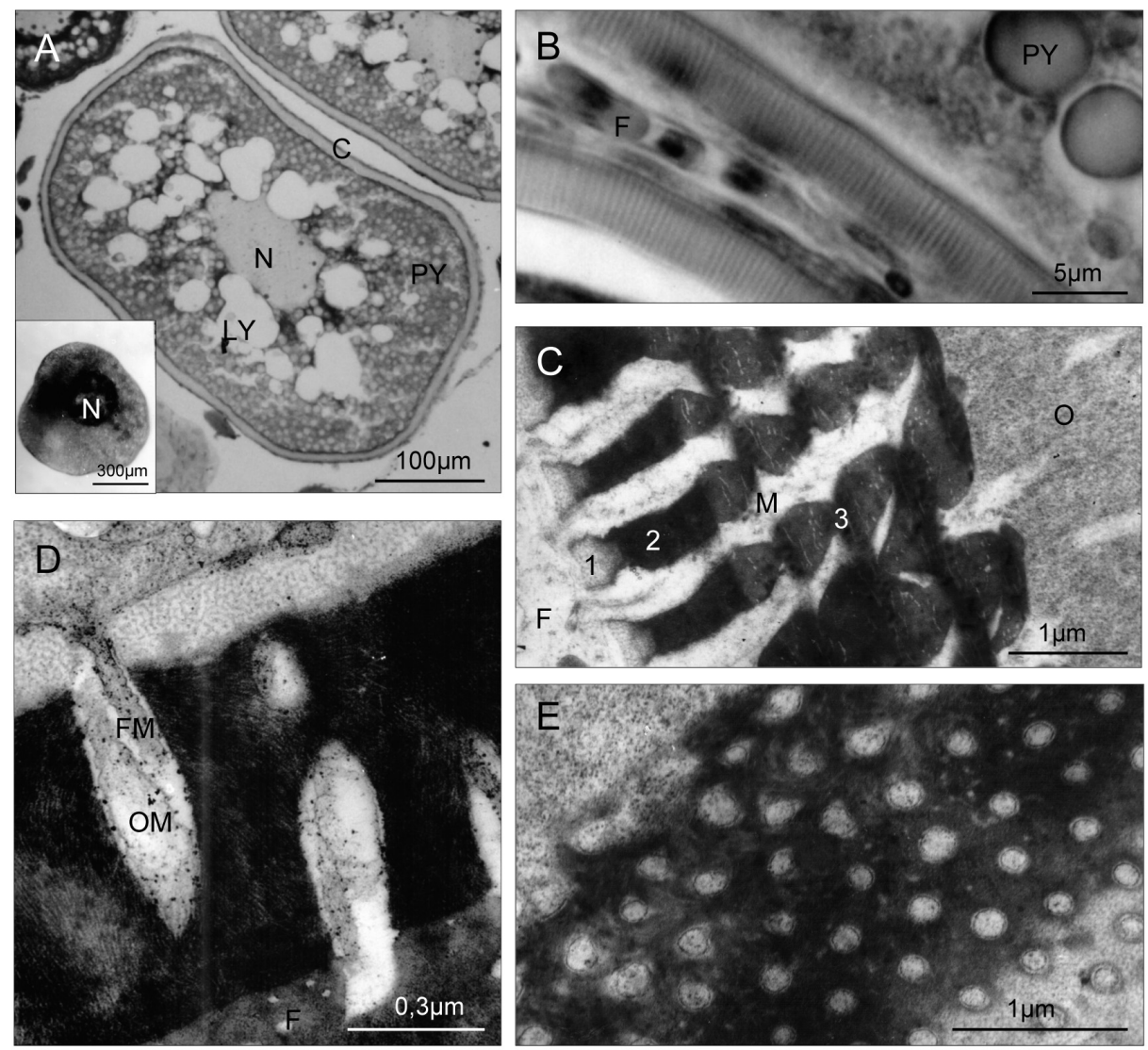

Figure 1: Fully grown oocyte of the whitemouth croacker and ultrastructural details of its chorion. A) Light microscopy of the oocyte (square); histological section. B) High magnification of the chorion showing its striation. C) Ultrastructural aspect of the envelope at this stage. D) Detail of the outer zone showing the apposition between both kinds of microvilli inside the channels. E) Pattern of channels crossing the egg envelope (cross section).

$\mathrm{N}$ : nucleus; LY: lipid yolk; PY: protein yolk; C: chorion; F: follicular cell; O: oocyte cytoplasm; 1,2 and 3: chorion zones; M: channels with microvilli; FM: follicular microvillus; OM: oocyte microvillus. A, B: PAS-hematoxyline stain; C, D, E: TEM microscopy.
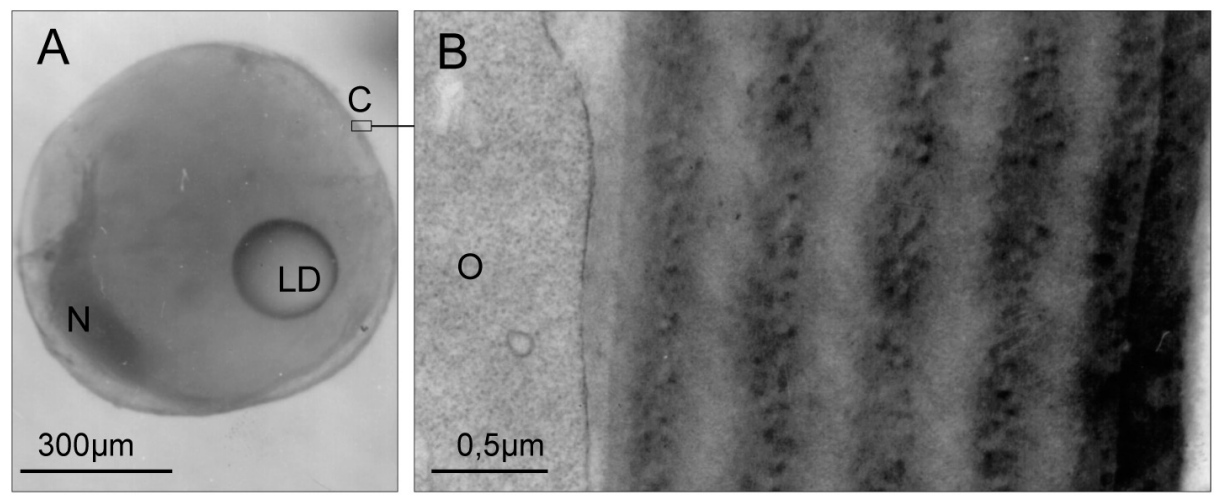

Figure 2: Mature ovulated oocyte of the whitemouth croacker and ultrastructural details of its chorion. A) Light microscopy of the oocyte. B) Ultrastructural aspect (TEM) of the envelope at this stage showing parallel bands of different electron density. N: nucleus; LD: lipid drop; C: chorion; O: oocyte cytoplasm. 

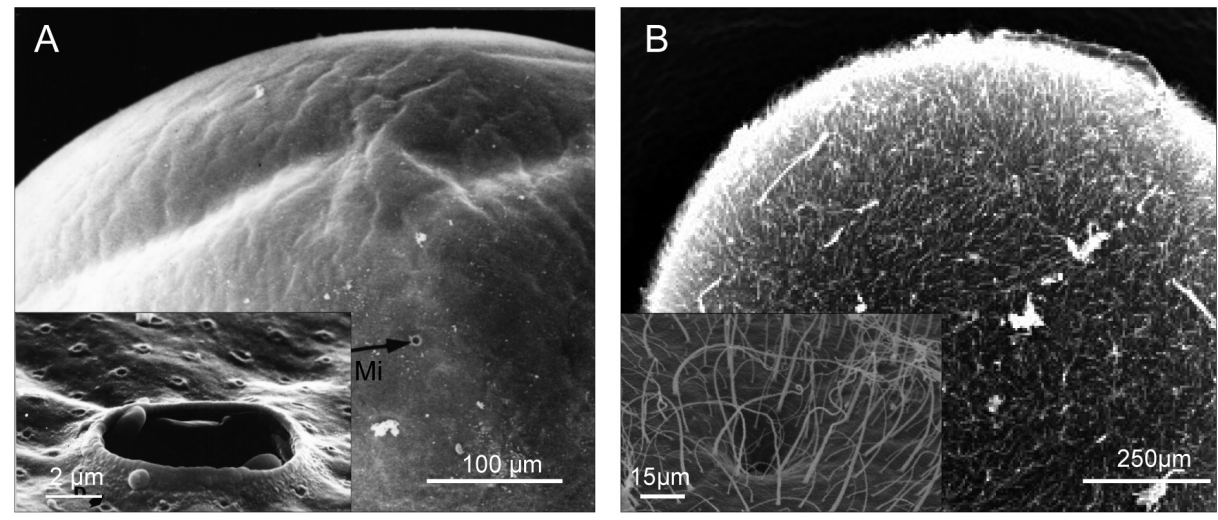

Figure 3: Animal pole of oocytes belonging to the fish species, whitemouth croaker and annual fish Austrolebias (SEM). Note the differences of the chorion surfaces: smooth in the case of pelagic egg (A) and highly ornamented with filaments in the demersal egg (B). Squares show high magnifications of the micropyles in both species. Arrow: micropyle at low magnification; Mi: micropyle:

glycoproteins are the only proteins that remain in the oocyte surface suggesting that the morphological changes observed following maturation might involve changes in the oocyte envelope protein composition. Following 2-DE electrophoresis 14 major polypeptides and some minor spots were detected. MALDI-TOF-MS analyses have shown no matching entries in the database (Berois et al., 2007). One limitation is the lack of genome sequencing or expressed sequence tag (EST) projects for this species. Proteomic studies currently underway could play an important role in evaluating changes in the expression levels of whitemouth croaker oocyte $\mathrm{ZP}$ proteins in response to environmental factors and determining whether an accurate and sensitive biomarker can be selected.

\section{ZPS SITES OF SYNTHESIS. EGG ENVELOPE GENES}

Regarding ZP synthesis, the earlier ultrastructural data on medaka gave support to the idea that this envelope was secreted by the oocyte itself (Tesoriero 1977, 1978). In the 1980s data was collected about the presence of an immunoreactive substance with antibodies against chorion proteins in the liver and blood of spawning medaka females (Hamazaki et al., 1985, 1987, 1989). Similar results were found for rainbow trout (Hyllner and Haux, 1992). A later study that characterized the three vitelline envelope proteins (VEP) cDNA of this species showed that VEP mRNAs were transcribed in the liver under estrogen regulation in both sexes (Hyllner et al., 2001). There was assumed a general agreement that the main proteins of the teleost chorion (specially zone 3 ) were synthesized in the hepatocyte under regulation of estradiol-17 $\beta$ (Hyllner et al., 1991; Oppen-Berntsen et al., 1992 a and b; Hyllner and Haux, 1992; Hyllner et al., 1994; Hyllner et al., 2001). In contrast to these findings, the synthesis of chorion proteins in pipefish (Begovac and Wallace, 1989), in the carp (Chang et al., 1996, 1997) and in zebrafish (Wang and Gong, 1999; Mold et al., 2001) was reported in the ovary. Therefore the sites of ZP synthesis differ among species, but the complexity is even greater because this condition affects different ZPs in the same fish. Examples are the dual expression of rainbow trout $\mathrm{ZPC}$ and gilthead sea bream ZPBa and ZPX in both liver and ovary (Modig et al., 2006). Liver expression appears to be regulated by estrogen while ovarian expression can either be under estrogenic control or independent of it (e.g. zebrafish, Liu et al., 2006).

Analyses of teleost fish ZP gene sequences have demonstrated that this group of vertebrates includes two classes of genes that encode $\mathrm{ZP}$ proteins further distinguished by their expression in the liver, in the ovary or both, depending on the species. The ancestral condition for vertebrates is ovary expression (Conner and Hughes, 2003). It has been hypothesized that teleostean fish experience a duplication event followed by a switch to hepatic expression of one of the paralogue genes and that the acquisition of dual sites of synthesis is the result of an ancient polyploidization event plus additional species-specific gene amplifications (Conner and Hughes, 2003). Probably the first step in ZP gene evolution was a gene duplication that might have originated both the ancestral ZPC gene and the precursor of the ZPA, ZPB and ZPX subfamilies. Because no ZPA gene has been found in fish, it has been assumed that it has been lost, probably through deletion events (Spargo and Hope, 2003). On the other hand the ZPX genes are present in fish, amphibians and birds, but not in mammals. It has been suggested that they have been lost through evolutionary mutations (Smith et al., 2005).

In the context of a comparative research project we are characterizing the expression of ZP genes in the whitemouth croaker and in annual fish by means of RT-PCR. With respect to the first species, we have isolated a first cDNA, (czp10 560 $\mathrm{bp}$ ) expressed in the liver. The deduced amino acid sequence presented $81 \%$ of identity with choriogenin L from Sparus aurata, another Perciforme (D'Alessandro et al., 2007). In annual fish (A. charrua) two cDNA, achzpL and achzpH (160 bp and $670 \mathrm{bp}$ respectively) have been identified, both expressed in the liver. The deduced amino acid sequence in both fragments showed identity values between 65 to $80 \%$ with ZPs from species belonging to diverse orders (Fundulus heteroclitus, Oryzias latipes, Sparus aurata and Danio rerio) (Ms in preparation)

\section{BIOMONITOR VALUE}

Teleosts are increasingly important indicators of environmental health. Considerable information exists about the impact 
that pollutants may cause on fish reproduction: on sex differentiation, gonad morphology and rates of gametogenesis and sex phenotypes (reviewed by Devlin and Nagahama, 2002; Arukwe and GoksØyr, 2003).

The fish oogenesis process has been shown to be a sensitive biomarker to environmental pollutants and endocrinedisrupting chemicals, which induce noticeable changes in the synthesis of fish oocyte proteins, including envelope proteins and vitellogenin (Vtg) (Arukwe et al., 2000; Arukwe and Goksøyr, 2003). The induction of vitellogenin is mainly used as a biomarker but it has been demonstrated that the expression of ZPs precedes that of Vtg (Arukwe et al., 2000). Furthermore, to use $\mathrm{ZP}$ proteins as biomonitor appear to have a higher potential than vitellogenin because, while subtle changes in VTg would not be a threat to the survival of the offspring, small changes in ZP expression or synthesis might cause differences in thickness and strength of the egg envelope. The consequences of these alterations could affect fertilization and polyspermy prevention and protection of the embryo during development (Arukwe et al., 1997; Arukwe and Goksøyr, 2003).

Some parameters related to regulation of ZP synthesis are involved in the selection of these proteins as accurate biomonitors. $E_{2}$ appears as the main regulator in most of the studied species (Modig et al., 2007) but it has been shown that other hormones, such as cortisol and androgens or physiological conditions, such as stress, affect estrogendependent regulation of $\mathrm{ZP}$ proteins in some species (Berg et al., 2004). Consequently, when proposing these proteins as biomonitors it is necessary to have first elucidated the sites and basal level of ZP expression for the species under research.

In order to provide a baseline to the potential effect of contaminants on an important economic fishery resource of the Rio de la Plata, our group analyzed the detailed structure, depositing dynamic and chemical composition of the oocyte envelope in the whitemouth croaker, M. furnieri. The assays performed on samples from three time periods were consistent and analogous in spite of the natural variable conditions of the estuary, which were emphasized under the influence of El Niño (1997-98). This information provides a useful baseline to assess future detrimental effects of pollutants on the oogenesis of this important renewable fishing resource (Berois et al., 2007). Currently we are working in order to establish the expression pattern of the $\mathrm{ZP}$ genes and its regulation in this species.

A comparable approach is being developed for annual fish. The species under research, A. charrua, inhabits a Uruguayan zone declared a Biosphere Reserve Area (UNESCO, 1976). Sex differentiation, determination of sexual strategy, and cellular aspects of gametogenesis of this annual fish have been established by our group (Arezo et al., 2007). The growing information about different topics of reproduction of $A$. charrua makes it a useful taxon to monitor contamination effects in a protected area.

\section{CONCLUSIONS AND PERSPECTIVES}

Current knowledge about fish egg envelope was summarized in the present paper. The information about organization and depositing at the ultraestructural level, protein composition, the multiple genes involved in the synthesis of this structure and its role in fertilization were analyzed comparatively. Our contribution is focused on increasing basic and applied knowledge about gamete biology in two phylogenetically distant fish species: the perciforme Micropogonias furnieri and the cyprinodontiforme Austrolebias charrua. In addition, fish chorion could be a feasible biomonitor of the aquatic environment. This condition is more relevant in species that are diminishing by pressure on the habitat or overfishing

Finally, studies of teleost fish reproduction support aquaculture in different areas of concern, one of these being the production of large number of healthy eggs that maintain fish culture at high levels. Endocrine regulation of spawning and new protocol development to rear embryos, fries and juveniles has been the main focus of many applied investigations. Nevertheless, there are many gaps of information about molecular and physiological mechanisms underlying oocyte development and maturation.

As teleosts represent the most diverse vertebrate group, to have access to further genome sequencing data and the application of approaches such as transcriptomic and proteomic in more fish clades will enhance our understanding of fish oocyte as a whole and help in the near future to develop useful biotechnological applications in aquaculture.

\section{AKNOWLEDGMENTS}

The authors acknowledge the financial support of the Facultad de Ciencias, PEDECIBA (Programa de Desarrollo de Ciencias Básicas), CSIC (Comisión Sectorial de Investigación, Universidad de la República) and ANNI (Agencia Nacional de Investigación e Innovación). Special thanks are extended to Dr. Mónica Brauer for her collaboration in TEM. We thank the reviewers that contributed with their suggestion to the improvement of the manuscript.

\section{REFERENCES}

ARENA G (1990) Evaluación de la captura máxima sostenible de la corvina blanca (Micropogonias furnieri) presente en el área operativa de la flota uruguaya mediante modelos de producción excedente. Frente Marít 7: 25-35.

AREZO MJ, PEREIRO L, BEROIS N (2005) Early development in the annual fish Cynolebias viarius. J Fish Biol 66: 1357-1370.

AREZO MJ, DALESSANDRO S, PAPA N, DE SÁ R, BEROIS N (2007) Sex differentiation pattern in the annual fish Austrolebias charrua (Cyprinodontiformes: Rivulidae). Tissue Cell 39: 89-98.

ARUKWE A, KNUDSEN FR, GOKSØYR A (1997) Fish zona radiata (egg shell) protein: A sensitive biomarker for environmental estrogens. Environ Health Perspect 105: 418-422.

ARUKWE A, CELIUS T, WALTHER BT, GOKSØYR A (2000) Effects of xenoestrogen treatment on zona radiata protein and vitellogenin expression in Atlantic salmon (Salmo salar). Aquat Toxicol 49:159-170.

ARUKWE A, GOKSØYR A (2003) Eggshell and egg yolk proteins in fish: hepatic proteins for the next generation: oogenetic, population, and evolutionary implications of endocrine disruption. Comp Hepatol 2, 4.

BEGOVAC P, WALLACE R (1989) Major vitelline envelope proteins in pipefish oocytes originate within the follicle and are associated with the Z3 layer. J Exp Zool 251: 56-73.

BERG AH, WESTERLAND L, OLSSON PE (2004) Regulation of Artic char (Salvelinus alpinus) egg shell proteins and vitellogenin during reproduction and in response to $17 \beta$ estradiol and cortisol. Gen Comp Endocrinol 135:276-285.

BEROIS N, BOLATTO C, BRAUER M, BARROS C (2004) Gametogenesis, histological gonadal cycle and in vitro fertilization in the whitemouth croaker (Micropogonias furnieri, Desmarest, 1823).J Appl Ichthyol 20: 169-175.

BEROIS N, AREZO MJ, CHALAR C, BRAUER MM, BARROS C (2007) Ultrastructure and protein composition of the oocyte envelope in the whitemouth croaker (Micropogonias furnieri, Desmarest, 1823, Sciaenidae, Perciformes). J Appl Ichthyol 23: 34-39. 
BONSIGNORIO D, PEREGO L, DEL GIACCO L, COTELLI F (1996) Structure and macromolecular composition of the zebrafish egg chorion. Zygote 4: 101-108.

BORK P, SANDER C (1992) A large domain common to sperm receptors (Zp2 and Zp3) and TGF-beta Type III receptor. FEBS Lett 300:237-240.

BRIVIO M, BASSI R, COTELLI F (1991) Identification and characterization of the major components of the Oncorhynchus mykiss egg chorion. Mol Reprod Dev 28: 85-93.

BRUMMETT A, DUMONT J (1979) Initial stages of sperm penetration into the egg of Fundulus heteroclitus. J Exp Zool 210:417-434

CHANG YS, WANG SC, TSAO CC, HUANG FL (1996) Molecular cloning, structural analysis and expression of carp ZP3 gene. Mol Reprod Dev 44: 295-304.

CHANG YS, HSU CC, WANG SC, TASO CC, HUANG FL (1997). Molecular cloning, structural analysis and expression of carp ZP2 gene. Mol Reprod Dev 46: 258-267.

CHAO LN (1978) Family Sciaenidae. In: Fisher W (ed) FAO species identification sheets for fisheries purposes. Western Central Atlantic (Fishing area 31). FAO, Rome, Vol. 6.

CONNER SJ, HUGHES DC (2003). Analysis of fish ZP1/ZPB homologous genes-evidence for both genome duplication and species-specific amplification models of evolution. Reproduction 126:347-352.

COTELLI F, ANDRONICO F, BRIVIO M, LORA LAMIA C (1988) Structure and composition of the fish egg chorion (Carassius auratus). J Ultrastruct Mol Struct Res 99: 70-78.

DALESSANDRO S, CHALAR C, BEROIS N (2007) Identificación de los genes responsables de la síntesis de las proteínas coriónicas en un recurso pesquero de importancia para Uruguay. In: XII Jornadas Científicas de la Sociedad Uruguaya de Biociencias.

DEVLIN RH, NAGAHAMA Y (2002) Sex determination and sex differentiation in fish: an overview of genetic, physiological and environmental influences. Aquaculture 208: 191-364.

DUMONT J, BRUMMETT A (1980) The vitelline envelope, chorion and micropyle of Fundulus heteroclitus eggs. Gamete Res 3:25-44.

EHRHARDT NM, ARENA GJ, VARELA ZM, ABELLA A, SÁNCHEZ EM, RÍOS CA, MORATORIO N (1977) Evaluación preliminar de los recursos demersales en el área común de pesca argentino-uruguaya. Instituto Nacional de Pesca, Informe técnico No 11.

FAO (1974) Informe del grupo de trabajo conjunto CAIM/CARPAS sobre la evaluación científica del estado de los stocks en el Atlántico sudoccidental. FAO, Rome, pp:1-60.

GURAYA S (1986) The cell and molecular biology of fish oogenesis. Monogr Dev Biol 18: 1-233.

HAMAZAKI T, IUCHI I, YAMAGAMI K (1985) A spawning female-specific substance reactive to anti-chorion (egg envelope) glycoprotein antibody in the teleost, Oryzias latipes. J Exp Zool 23: 269-279.

HAMAZAKI T, IUCHI I, YAMAGAMI K (1987a) Production of a spawning female-specific substance in hepatic cells and its accumulation in the ascites of the estrogen-treated adult fish, Oryzias latipes. J Exp Zool 242:325-332.

HAMAZAKI T, NAGAHAMA Y, IUCHI I, YAMAGAMI K (1989) A glycoprotein from the liver constitutes the inner layer of the egg envelope (zona pellucida interna) of the fish, Oryzias latipes. Dev Biol 133:101-110.

HART N (1990) Fertilization in teleost fishes: mechanisms of sperm-egg interactions. I Rev Cytol 121:1-66.

HART N, DONOVAN M (1983) Fine structure of the chorion and site of sperm entry in the egg of Brachydanio. J Exp Zool 227: 277-296.

HYLLNER SJ, OPPEN-BERNTSEN DO, HELVIK JV, WALTHER BT, HAUX C (1991) Oestradiol 17- $\$$ induces the major vitelline envelope proteins in both sexes in teleosts. J Endocrinol 131: 229-236.

HYLLNER SJ, HAUX C (1992) Immunochemical detection of the major vitelline envelope proteins in the plasma and oocytes of the maturing female rainbow trout, Oncorhynchus mykiss. J Endocrinol 135:303-309.

HYLLNER SJ, SILVERSAND C, HAUX C (1994) Formation of the vitelline envelope precedes the active uptake of vitellogenin during oocyte development in the rainbow trout, Oncorhynchus mykiss. Mol Reprod Dev 39:166-175.

HYLLNER SJ, WESTERLUND L, OLSSON PE, SCHOPEN A (2001). Cloning of rainbow trout egg envelope proteins: members of a unique group of structural proteins. Biol Reprod 64: 805-811.

ISAAC-NAHUM V (1988) Synopsis of biological data on the whitemouth croaker Micropogonias furnieri (Desmarest 1923) FAO Fisheries Synopsis 150:1-35.

KUDO S (2000) Enzymes responsible for the bactericidal effect in extracts of vitelline and fertilization envelopes of rainbow trout eggs. Zygote 8: 257-65.
KUDO S, INOUE M (1989) Bacterial action of fertilization envelope extract from eggs of the fish Cyprinus carpio and Plecoglosus altivelis. J Exp Zool 250: $219-228$.

LISTCHER ES, WASSARMAN PM (2007) Egg extracellular coat proteins: from fish to mammals. Histol Histopathol 22:337-347.

LIU X, WANG H, GONG Z (2006) Tandem repeated zebrafish zp3 genes posses oocyte-specific promoters and are insensitive to estrogen induction. Biol Reprod 74:1016-1025.

MODIG C, MODESTO T, CANÀRIO AVM, CERDÀ J, VON HOFSTEN J, OLSSON PE (2006). Molecular characterization and expression pattern of zona pellucida proteins in gilthead seabream (Sparus aurata). Biol Reprod 75:717-725.

MODIG C, WESTERLUND L, OLSSON PE (2007) Oocyte zona pellucida proteins. In BABIN PJ, CERDÀ J, LUBZENS E (eds) The fish oocyte. From basic studies to biotechnological applications. Dordrecht:Springer. Pp: 113-139.

MODIG C, RALDÚA D, CERDÀ J, OLSSON PE (2008). Analysis of vitelline envelope composition during oocyte development in gilthead seabream (Sparus aurata). Mol Reprod Dev 75:1351-1360.

MOLD DE, KIM IF, TSAI CM, LEE D, CHANG CY, HUANG RC (2001) Cluster of genes encoding the major egg envelope protein of zebrafish. Mol Reprod Dev 58: 4-14.

MYERS GS (1952). Annual fishes. Aquar J 23: 125-141.

OPPEN-BERNTSEN D, HELVIK J, WALTHER B (1990) The major structural proteins of cod (Gadus morhua) eggshell and protein crosslink during teleost egg hardening. Dev Biol 137:258-265.

OPPEN-BERNTSEN D, HYLLNER S, HAUX C, HELVIK J, WALTHER B (1992 a): Eggshell zona radiata-proteins from cod (Gadus morhua): extra-ovarian origin and induction by estradiol-17 $\beta$. Int J Dev Biol 36:247-254.

OPPEN-BERNTSEN D, GRAM-JENSEN E, WALTHER B (1992 b): Zona radiata proteins are synthesized by rainbow trout (Oncorhynchus mykiss) hepatocytes in response to oestradiol-17 $\beta$. J Endocrinol 135:293-302.

RIZZO E, SATO Y, BARRETO BP, GODINHO HP (2002) Adhesiveness and surface patterns of eggs in neotropical freshwater teleosts. J. Fish Biol 61: 615-632.

SCAPIGLIATI G, CARCUPINO M, TADDEI A, MAZZINI M (1994) Characterization of the main egg envelope proteins of the sea bass Dicentratus labrax L. (Teleostea, Serranidae). Mol Reprod Dev 38:48-53.

SMITH J, PATON IR, HUGHES DC, BURT DW (2005) Isolation and mapping the chicken zona pellucida genes: an insight into the evolution of orthologous genes in different species. Mol Reprod Dev 70: 133-145.

SPARGO SC, HOPE RM (2003). Evolution and nomenclature of the zona pellucida gene family. Biol Reprod 68: 358-362.

TESORIERO J (1977) Formation of the chorion (zona pellucida) in the teleost, Oryzias latipes. II Polysaccharide cytochemistry of early oogenesis. J Histochem Cytochem 25:1376-1380.

TESORIERO J (1978) Formation of the chorion (zona pellucida) in the teleost, Oryzias latipes. III Autoradiography of $[3 \mathrm{H}]$ proline incorporation. J Ultrastruct Res 64:315-326.

UNESCO, 1976. The MAB Programme. UNESCO - MAB Biosphere Reserves Directory. http://www.unesco.org/mabdb/br/brdir/directory/ biores. asp? code $=$ URU $+01 \&$ mode $=$ all.

WALLACE RA, SELMAN K (1981) Cellular and dynamic aspects of oocyte growth in teleosts. Am Zool 21: 325-343.

WANG H, GONG Z (1999) Characterization of two zebrafish cDNA clones encoding egg envelope proteins ZP2 and ZP3. Biochim Biophys Acta 1446: 156-160.

WOURMS JP (1964) Comparative observations on the early embryology of Nothobranchius taeniopygus (Hilgendorf) and Aplocheilicthys pumilis (Boulenger) with special reference to the problem of naturally ocurring embryonic diapause in teleost fishes. Annual Report E Afr Freshwat Fish Res Organ Appendix H, pp. 68-73.

WOURMS JP (1967) Annual Fishes. In: WILT FH, WESSELS N (eds) Methods in Developmental Biology. New York: Thomas and Crowell Company. pp: $123-137$.

WOURMS JP (1972a) The developmental biology of annual fishes I. Stages in the normal development of Austrofundulus myersi Dahl. J Exp Zool 182:143-168.

WOURMS JP (1972b) The developmental biology of annual fishes. II. Naturally occurring dispersion and reaggregation of blastomeres during the development of annual fish eggs. J Exp Zool 182: 169-200.

WOURMS JP (1972c) The developmental biology of fishes. III. Preembryonic diapause of variable duration in the eggs of annual fishes. J Exp Zool 182: $389-414$ 